\title{
Necessidade de pesquisa bibliográfica extensa para evitar omissões
}

Este Editorial, diverso dos usualmente escritos na nossa e demais revistas médicas, tem algumas mensagens peculiares que poderão ser de utilidade aos colegas.

Ao longo dos séculos, a história tem registrado acontecimentos em todos os setores das atividades humanas, entretanto, apesar de escritos e publicados, nem sempre seus autores são devidamente lembrados e citados, embora a Lei da Prioridade estabeleça claramente os critérios para tal. Os fatores dessas omissões são vários. Sem entrar em detalhes, vão desde a falha na pesquisa, apesar da boa intenção, à negligência, à limitação do acesso às fontes fidedignas até o dolo em que o ego e a ambição condicionam este comportamento premeditado. Têm ocorrido continuamente nos mais variados graus, em todas as partes do mundo, nas mais diversas atividades e épocas. Sem prognosticar, cremos lamentavelmente que este "status quo" deverá ainda continuar.

Na nossa especialidade, temos visto ocorrer também. Tivemos a oportunidade de publicar um editorial na nossa revista sobre esta matéria. Chamamos a atenção para a importância do rigor na pesquisa bibliográfica antes de iniciar um trabalho científico, no sentido de posicionar a mensagem de qualquer natureza, para não omitir os que previamente já haviam publicado algo similar e para os autores não se sentirem omissos. O inverso tem determinado reações de todos os níveis, em qualquer campo da atividade humana. Um dos aspectos rotineiros publicados nas revistas médicas de qualquer especialidade e país está na seção de "Cartas ao Editor", em que autores sentem-se negligenciados quando sua contribuição científica publicada sobre uma matéria não é referida no texto e nem na bibliografia de um artigo. Elegantemente, a cobrança é dirigida ao autor via editor, para conhecimento dos leitores e registro de sua queixa. As querelas entre o omisso e o autor têm todos os níveis, quer via revista, quer diretamente entre eles, com ou sem interferência da justiça. Na área médica, assim como em outras, a fórmula mágica é simples e recai sempre na rigorosa pesquisa bibliográfica. Não há como ser diferente. A nossa revista que recém cria o seu espaço, já registra estes detalhes. Na verdade, a cobrança é salutar para quem de direito e para o autor, no sentido de ser mais criterioso ao publicar o seu artigo.

O motivo principal deste editorial é o de registrar uma mensagem gratificante e que deve servir de exemplo a todos, militantes ou não na Cirurgia Plástica particularmente. Um dos pioneiros de maior qualificação na Cirurgia Plástica no Brasil, com o qual tivemos o privilégio de conviver nos congressos e de compartilhar da sua amizade no auge das suas atividades, foi o Prof. Dr. Jorge Fonseca Ely. Treinado e qualificado para atuar nas áreas da cirurgia reparadora e estética, deixou um legado científico em todos os setores da especialidade como pioneiro, registrando no seu tempo por meio do livro Cirurgia Plástica, cuja segunda edição foi publicada em 1980. Tivemos o privilégio de ter um exemplar com a sua dedicatória. Quando foi publicado, não havia no país um livro em nossa especialidade com a sua amplitude. Atualmente, a superespecialização tem determinado publicações específicas para cada setor do corpo. O livro na época era a expressão global didática e científica, porém o tempo passou. Não teria sentido ser re-editado caso não viesse a ser atualizado. O livro do Prof. Jorge Fonseca Ely ficou registrado na história dos pioneiros, porém sempre aberto para referências. Quantas foram as técnicas publicadas no final do século XIX e nos primórdios do século XX cujos pioneiros deixaram as bases de muitas que são utilizadas atualmente com os respectivos refinamentos. Nossa revista publicou um artigo tipo relato de caso, de autoria do Prof. Dr. Fernando Passos da Rocha e colaboradores, em que utilizam um esquema existente no livro do Prof. Ely, sem a necessária citação bibliográfica. $\mathrm{O}$ autor com $\mathrm{PhD}$ e coautores na mais elevada qualificação, com a maior elegância e postura, se redimiram perante a omissão, fato esse que também ocorre em circunstâncias várias, dentro e fora do país, porém nem sempre com a categoria dos que se escusaram.

A nossa mensagem tem o escopo de cumprimentar os envolvidos na cobrança e nas escusas, raramente neste nível registradas nos Anais da Medicina e fora dela. É um exemplo para ser divulgado. Parabenizamos os envolvidos. Finalizamos para enfatizar uma vez mais sobre o rigor da pesquisa bibliográfica, sem mais outros comentários.

\section{Ricardo Baroudi}

Editor 